University of Nebraska - Lincoln

DigitalCommons@University of Nebraska - Lincoln

Spring 9-17-2021

\title{
Usage Statistics of E-resources during Pandemic Period: A Case Study of Chandigarh University Library
}

\author{
Ram Veer \\ Chandigarh University, Mohali, Punjab, dylibrarian@cumail.in \\ Subhajit Panda \\ Chandigarh University, Mohali, Punjab, suvapanda007@gmail.com
}

Follow this and additional works at: https://digitalcommons.unl.edu/libphilprac

Part of the Information Literacy Commons

Veer, Ram and Panda, Subhajit, "Usage Statistics of E-resources during Pandemic Period: A Case Study of Chandigarh University Library" (2021). Library Philosophy and Practice (e-journal). 6339.

https://digitalcommons.unl.edu/libphilprac/6339 


\title{
Usage Statistics of E-resources during Pandemic Period: A Case Study of Chandigarh University Library
}

\author{
Dr. Ram Veer and Subhajit Panda \\ Deputy Librarian - Chandigarh University Mohali, Punjab (India) \\ Email:dylibrarian@,cumail.in \\ Assistant Librarian - Chandigarh University Mohali, Punjab (India) \\ Email: suvapanda007@gmail.com
}

\begin{abstract}
Electronic resources are the electronic representation of information. Because of the easy accessibility, low cost and effective presentation with multimedia tools, e-resources have become the most popular source of information. The present research focuses on the usage statistics of e-resources during the pandemic period lockdown and restricts its scope to Chandigarh University Library. This study survey was conducted by distributing 200 questionnaires structured on a Google Form among the students, staff and faculty members of Chandigarh University. Out of all distributed questionnaires, 158 questionnaires were selected as a valid response for the study. Various statistical methods have been used for the analysis of the survey data. According to the findings, the majority of the library users are aware of the e-Resources available in the CU Library \& use them efficiently according to their particular needs. Furthermore, the paper describes the difficulties students and faculty members faced in obtaining e-resources, as well as their perspectives on the utility of the e-resources.
\end{abstract}

Keywords: E-resources, Information Dissemination, Usage Statistics, Library Services, Pandemic Period, Covid-19, National Lockdown 


\section{Introduction}

Libraries have witnessed a great metamorphosis in recent years, both in terms of collection development, service structure, policies and practices. The print medium is increasingly giving way to the electronic form of materials (Poornima \& IRN, 2005). In the 21 st century due to competitive pressure from different information providers and emerging new technologies \& services generates a new information era (Simmonds \& Andaleeb, 2001). The rapid advancement of information and communication technology has brought a revolutionary change in the information scenario and gives rise to several options to handle varied information sources conveniently and effortlessly. Electronic resources (Eresources) have become the most sought after modern library's reserves in satisfying the diverse needs of students, teachers, and researchers with minimum risk and time. Information technology has changed the world and has become one of the essential tools for retrieving information. Electronic information resources have acquired a significant portion of library collections. The aforementioned is very important for university libraries since most of them call for more and more research work.

During the worldwide lockdown due to the COVID-19 pandemic, the importance of eResources is phenomenal as the educational institutions have shifted from physical to virtual sessions. Users prefer more for e-Resources, virtual libraries, remote access facilities in this critical situation. Despite innumerable advantages of e-resources, there are certain problems also relating to their awareness, usage, maintenance, management, etc. which need collaborative efforts of professionals and all other bodies associated with the creation, distribution and use of these resources to establish the sound practices (Mitra, 2020). The current study examines the awareness level, demands, and popularity of e-Resources among Chandigarh University library users, as well as the level of satisfaction and various challenges they confront.

\section{About Chandigarh University}

Chandigarh University (CU) is a full-fledged, unitary, teaching \& residential university established by the Punjab State Legislature and is recognized by the University Grants Commission under Section 2(f) with the right to confer degrees as per Section 22(1) of the UGC Act, 1956. Since its inception, it has progressively tried to realize the aims of the noble Founder Vice-Chancellor Prof. (Dr.) R S Bawa and has had the unique good fortune of having a succession of eminent Vice-Chancellors to guide its destinies.

During the last ten years, Chandigarh University is a leading university envisioned to excel in research, innovation \& entrepreneurship provides inspirational learning to nurture our students to lead the professional world. Ranked among Asia's best \& fastest growing educational institutes with approximately 16 Departments with 202 courses of Study and over 7000 members on its teaching and non-teaching staff. The University campus, including the colleges, hostels and playgrounds occupies an area of about 120 acres.

\section{Literature Review:}

The importance and wide ranging scope of electronic re-sources for general communication, information retrieval and instructional delivery to support teaching and research activities in tertiary educational institutions is acknowledged worldwide. The 
literature also shows that a number of relevant studies have been carried out on the use of e- re-sources by lecturers, research scholars and students world-wide.

Shuling (2007) examined the readers' present conditions, difficulties and requirements of using e-recourses in the Library of Shaanxi University of Science and Technology with a valid sample size of 909 including teachers and students on the campus. The findings of the study suggest a satisfaction level of 50\% among library users. In their study, Nikam \& Pramodini (2007) described the use of e-journals and databases (subscribed by the UGCInfoNet consortium) by University of Mysore users, analysed the use of E-resources and user satisfaction levels. Haridasan \& Khan (2009) presented in their paper about the importance of e-resources in the National Social Science Documentation Centre (NASSDOC) library in New Delhi, India and determine their usage, performance, degree of user satisfaction, and barriers faced in the access of e-resources. It also attempts to find out the users' views about computer literacy among social scientists. Jogan (2015) examined postgraduate students' views (with a random sample from 50 PG students) on the access, awareness and usage in facilitating their research and their satisfaction with the sources and services currently provided by the library of Gulbarga University. Similarly, Kurian \& Nagarajan (2018) highlighted the results of a study on the utilization of open access resources among research scholars of Annamalai University. Thanuskodi (2012) used a valid data sample of 180 potential users to investigate the use of e-resources by postgraduate students and research scholars of the Faculty of Arts in the Annamalai University. According to the survey, the majority of users are aware of the availability of e-resources. In his paper, N. \& N. (2019) described the awareness, access and usage of Eresources available in the Arts and Science Colleges Faculty Members in Erode District. With 280 valid samples, the study was conducted using a questionnaire method. And the findings identified the popularity of e-Journals among male faculties \& e-Books among female ones. Matonkar \& Dhuri (2021) explored the awareness and use of open access resources (OARs) by Faculty and students of Ponda Education Society's (PES's) colleges. A questionnaire-based survey method has been used with a total of 278 library users filled in the form. The findings show that almost $40 \%$ of respondents are not aware of the OARs in the college. Livina \& Mole (2021) investigated the use of electronic resources by the academic staff in the Nigerian University libraries during the Corona Virus lockdown. The study was carried out with a sample size of 313 collected using the simple random sampling technique and the collected data were analyzed using descriptive statistics.

\section{Significance of the Study}

In the present era of information explosion-more and more publications are becoming Web-concerned. Most of the social science libraries have changed the contemporary outlook towards functions and services. The environment is rapidly changing to an electronic one. The investigators decided to conduct this study for measuring the usage of e-resources by students, staff and faculty members in Chandigarh University.

\section{Objectives of the Study:}

The primary focus of this study is to analyze the usage statistics of e-resources of Chandigarh University library during the recent pandemic period by conducting a survey to assess the benefits of the e-resources over conventional sources of information.

The main objectives of the present study are as follows: 
1) To find out the awareness of users' about available e-resources.

2) To study the purpose and utilization of e-resources.

3) To find out the frequency of using e-resources.

4) To find out the hindrances and problems faced by the users while accessing and using e-resources.

5) To study the level of satisfaction of users about avail-ability and coverage of eresources.

6) To study the preferred format for using e-resources.

7) To study the satisfaction level of users about infra-structure to support the access of e-resources.

8) To suggest suitable recommendations to improve facilities and services related to the use of e-resources.

\section{Methodology}

Keeping in view the aforementioned objectives in mind, a structured questionnaire was designed using the Google form to collect data from the users of e-resources in Chandigarh University. The questionnaire contains various questions pertaining to the awareness and use of e-resources. For this purpose, a total of 200 questionnaires were distributed among students, staff \& faculty members both online \& printed forms, as per the requirements. Out of 200 distributed questionnaires, 158 valid questionnaires were collected and then data was analysed, tabulated, interpreted and presented in this research paper. Due to lockdown \& unavailability of the email-ids of a majority portion of the students (particularly), the survey took almost six months (February 2021 to August 2021) to complete.

\section{Survey Design:}

The study was limited to the students, staff and faculty members of Chandigarh University Mohali, Punjab (India). Therefore, the survey of the study was designed to assess \& interpret the use of e-resources, their frequency \& purposes at the time of national lockdown when the physical access of information is almost impossible for the library users of Chandigarh University. Several types of questions like the open-end, close-end, single answer, multiple-choice based, Likert scale based, explanatory, include in the questionnaire. Before beginning the actual "Questionnaire Section", the Google form questionnaire included a "Demographic Section" to collect some general information such as age, gender, department, and designations of a specific user in order to more precisely represent the sample universe.

\section{Data Analysis:}

Analysis of data is the ultimate step in the research process. It is the link between raw data and significant results leading to conclusions. After the data collection is over from the finalize 158 questionnaires, the data cleansing process was performed with the help of spreadsheet software (MS Excel) for enhanced visualization. The data were then analysed according to various parameters set to meet the main objectives of the study. This process of analysis has to be result-oriented.

\section{Population Study:}

In research, all the individual samples are not counted equally to the population. There are several parameters to characterise a sample and their contribution to the research process. 
Thus, in order to analyse the characteristics of participant samples in this study, the study population was classified into age \& sex, as well as designation \& department in the institution.

\subsection{Age-wise Distribution of Respondents:}

The age of the professionals usually plays a vital parameter in performance measurement. Hence, it is pretty imperative to know the distribution of the library workforce in terms of their age. The respondents in five distinct age groups, from the youngest 17 years to the oldest 51 years, provided the following responses, as shown in the table below.

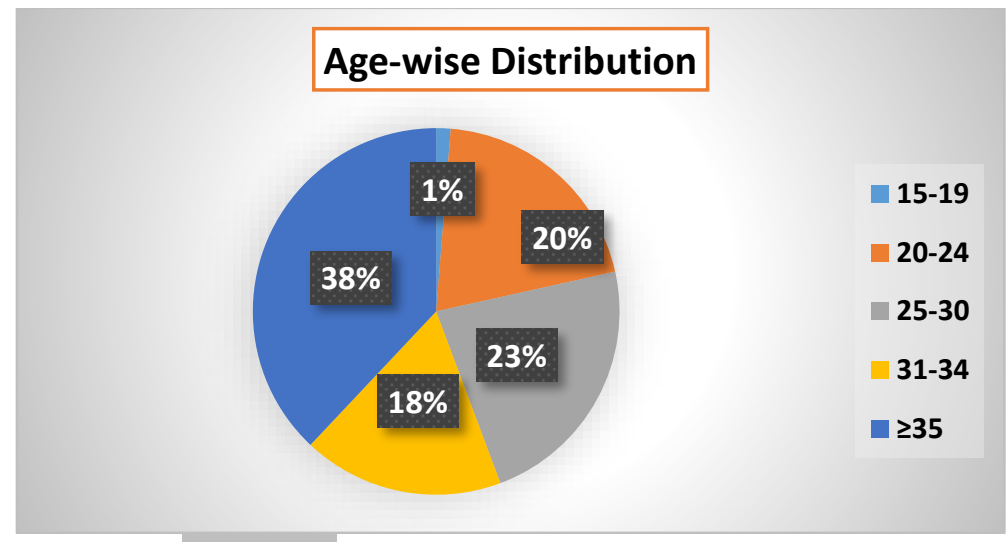

Figure 1: Age-wise Distribution of Respondents

According to Figure 1, the age of the majority of the sample respondent (38\% or 60) belongs to $\geq 35$, followed by $25-30$ age group \& $20-24$ age group with $23 \%$ (36) \& $20 \%$ (32) respondent respectively.

\subsection{Sex-wise Distribution of Respondents:}

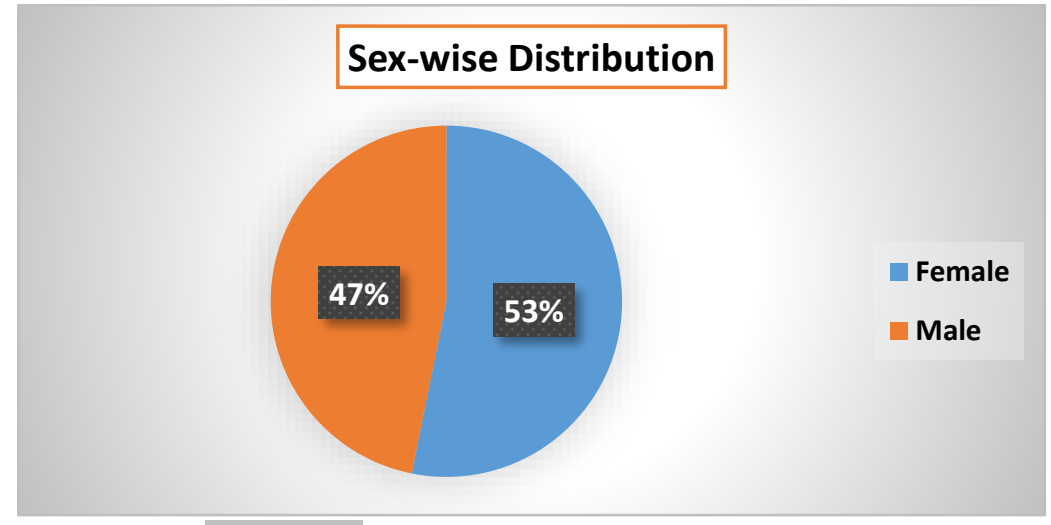

Figure 2: Sex-wise Distribution of Respondents

The distribution of the population by sex is one of the most significant demographic groupings. The personal detail section of the questionnaire provides sex information can be seen from Figure 2. In the present research, as reflected, the sample respondents of the study occupy $53 \%$ (84) of the male respondent and $47 \%$ (74) of the female respondent in the Chandigarh University significantly use e-resources available through the library for different purposes.

\subsection{Category-wise Distribution of Respondents:}




\section{Category-wise Distribution}

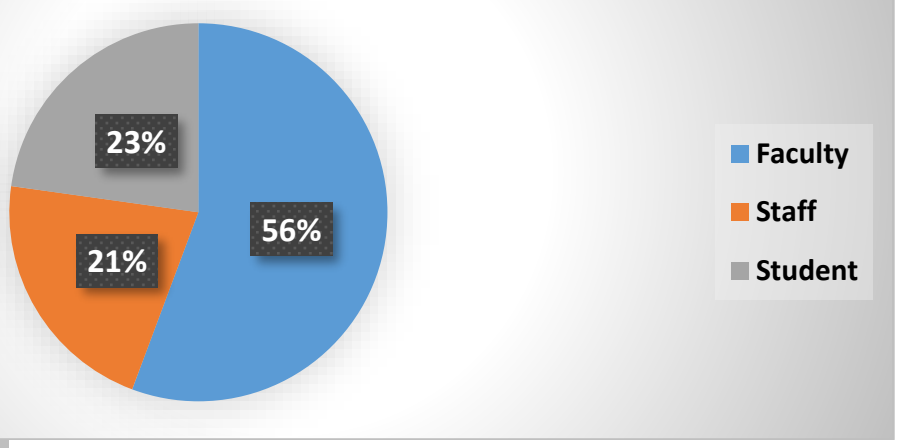

Figure 3: Category Wise Distribution of Respondents

The responses were obtained across Chandigarh University, and the respondents were divided into three categories: faculty, staff, and students. However, out of the 200 circulated questionnaires, the researchers were able to gather $158(79 \%)$ completed questionnaires from Chandigarh University library users through earnest and continuous efforts. Faculty Members had the highest percentage of responses ( 88 or 56\%), followed by Students (36 or 23\%) \& Staff Members had the lowest response rate (34 or 21\%).

\subsection{Department-wise Distribution of Respondents:}

\begin{tabular}{|c|c|c|c|}
\hline $\begin{array}{l}\text { Sr. } \\
\text { No. }\end{array}$ & Department & $\begin{array}{c}\text { No of } \\
\text { Respondent }\end{array}$ & $\begin{array}{l}\text { \%age of } \\
\text { respondent }\end{array}$ \\
\hline 1 & Library & 36 & $23 \%$ \\
\hline 2 & $\begin{array}{l}\text { University Institute of Catering \& Hotel } \\
\text { Management (UICHM) }\end{array}$ & 24 & $15 \%$ \\
\hline 3 & University Institute of Law (UIL) & 22 & $14 \%$ \\
\hline 4 & $\begin{array}{l}\text { University Institute of Agriculture Science } \\
\text { (UIAS) }\end{array}$ & 14 & $9 \%$ \\
\hline 5 & University Institute of Management (UIM) & 14 & $9 \%$ \\
\hline 6 & $\begin{array}{l}\text { University Institute of Applied Sciences } \\
\text { (UIAS) }\end{array}$ & 12 & $8 \%$ \\
\hline 7 & University Institute of Engineering (UIE) & 12 & $8 \%$ \\
\hline 8 & $\begin{array}{l}\text { University Institute of Teacher Training \& } \\
\text { Research (UITTR) }\end{array}$ & 8 & $5 \%$ \\
\hline 9 & $\begin{array}{l}\text { University Institute of Art \& Architecture } \\
\text { (UIAA) }\end{array}$ & 6 & $4 \%$ \\
\hline 10 & $\begin{array}{l}\text { University Institute of Liberal Arts \& } \\
\text { Humanities (UILAH) }\end{array}$ & 4 & $3 \%$ \\
\hline 11 & Others & 6 & $4 \%$ \\
\hline \multicolumn{2}{|r|}{ Total } & 158 & $100 \%$ \\
\hline
\end{tabular}


Table 1: Department-wise Respondent Distribution Table

For ensuring collection of perceptions from the library users of each departments, almost all departments are covered under the study (see table 1). Out of the 158 respondents, Library covers majority of the respondent (36 or $23 \%$ ). In next, there are two closely followed department viz. University Institute of Catering \& Hotel Management (UICHM) \& University Institute of Law (UIL) with $15 \%$ (24) or 14\% (22) respondent coverage respectively.

\section{Survey Result Analysis and Discussion}

The questionnaire section of the Google Form contained 14 unique questions (survey questions or SQ) to identify the actual usage statistics of e-resources of Chandigarh University library by examine different angles.

\section{1. [SQ1]- Awareness about E-resources}

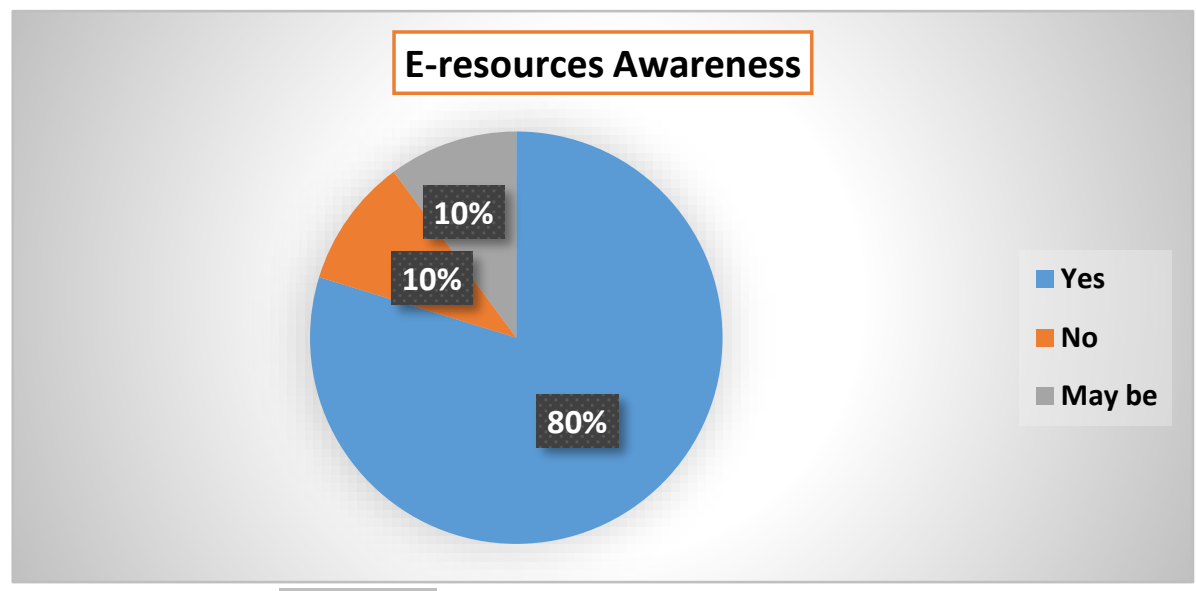

Figure 4: Awareness about E-resources

SQ1 deals with the awareness of the respondents about the e-resources provided by the library. According to the survey result (see Figure 4), 80\% (126) of the respondents were aware of the e-resources, whereas, only 10\% (16 each) respondents do not know or may not be aware of the E-resources provided by the university library.

\section{2. [SQ2]- Medium of Awareness about E-resources}

\begin{tabular}{|c|l|c|c|}
\hline Sr. No. & Awareness Medium & $\begin{array}{c}\text { No of } \\
\text { Respondent }\end{array}$ & $\begin{array}{c}\text { \% age of } \\
\text { respondent }\end{array}$ \\
\hline 1 & Library website & 48 & $30 \%$ \\
\hline 2 & Facebook & 0 & $0 \%$ \\
\hline 3 & Whatsapp & 4 & $3 \%$ \\
\hline 4 & E-learning Account & 20 & $13 \%$ \\
\hline 5 & Help from library staff & 22 & $14 \%$ \\
\hline 6 & Designated wall notice boards & 4 & $3 \%$ \\
\hline 7 & Newsletter & 0 & $0 \%$ \\
\hline 8 & $\begin{array}{l}\text { Help from Fellow Scholars/ } \\
\text { Supervisor }\end{array}$ & 20 & $13 \%$ \\
\hline 9 & Personal Effort & 34 & $22 \%$ \\
\hline
\end{tabular}




\begin{tabular}{|c|c|c|c|}
\hline 10 & Others & 6 & $4 \%$ \\
\hline \multicolumn{2}{|c|}{ Total } & $\mathbf{1 5 8}$ & $\mathbf{1 0 0} \%$ \\
\hline
\end{tabular}

Table 2: Medium of Awareness about E-resources

SQ2 recognised nine (9) possible awareness mediums in addition to other possibilities from which Table 2 shows the awareness of e-resources among the respondents. With a majority, 30\% (48) of the respondents were aware of the E-resources through library websites. Whereas, 22\% (34) were aware of the E-resources by their personal efforts and in next 14\% (22) respondents take the help from library staff.

\section{3. [SQ3]- Purpose of use E-resources}

\begin{tabular}{|c|l|c|c|}
\hline Sr. No. & Purpose of use & $\begin{array}{c}\text { No of } \\
\text { Respondent }\end{array}$ & $\begin{array}{c}\text { \% age of } \\
\text { respondent }\end{array}$ \\
\hline 1 & Communication & 16 & $10 \%$ \\
\hline 2 & Assignments & 22 & $14 \%$ \\
\hline 3 & Lecture requirements & 43 & $27 \%$ \\
\hline 4 & Recreation & 6 & $4 \%$ \\
\hline 5 & Support teaching activities & 24 & $15 \%$ \\
\hline 6 & Professional research & 42 & $27 \%$ \\
\hline 7 & Administrative purposes & 2 & $1 \%$ \\
\hline 8 & Others & 3 & $2 \%$ \\
\hline & Total & $\mathbf{1 5 8}$ & $\mathbf{1 0 0 \%}$ \\
\hline
\end{tabular}

Table 3: Purpose of Use E-resources

SQ3 purposely identified some common options (7 with a other option) about the most beneficial purpose to develop a close ended question. Table 3 elaborates that majority of the users prefer to use e-resources for making lecturer notes (with 43 or $27 \%$ coverage), which is closely followed by professional research (42 or $\sim 27 \%$ ), further followed by support teaching activities ( 24 or $15 \%$ ) because they feel that e-resources are time saving, more informative, more useful and less expensive.

\section{4. [SQ4]- Location for Accessing E-resources}

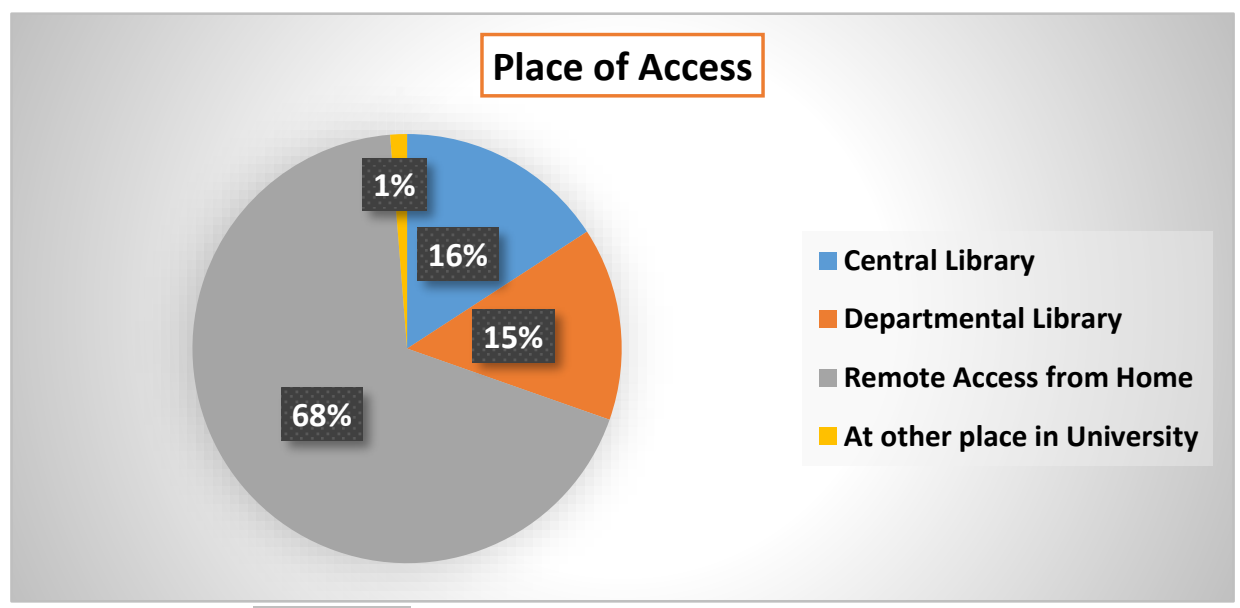

Figure 5: Location for Accessing E-resources

SQ4 tries to identify the most favourable place for accessing E-resources by the sample respondents. In response to the question (Figure 5), majority of respondents used remote 
access of the E-resources from Home 108 (68.3\%). It is followed by Central Library (25 or $16 \%$ ) \& Departmental Library (23 or 15\%). Only a few respondents ( 2 or $1 \%$ ) used to access e-resources from other places in University.

\section{5. [SQ5]- Frequency of use of e-resources}

\begin{tabular}{|c|c|c|c|c|c|}
\hline \multirow{2}{*}{ Sr. No. } & \multirow{2}{*}{ Use Frequency } & \multicolumn{4}{|c|}{ No of Respondent } \\
\hline & & Faculty & Staff & Student & Overall \\
\hline 1 & Daily & $\begin{array}{c}8 \\
(9 \%)\end{array}$ & $\begin{array}{c}0 \\
(0 \%)\end{array}$ & $\begin{array}{c}1 \\
(3 \%)\end{array}$ & $\begin{array}{c}9 \\
(6 \%)\end{array}$ \\
\hline 2 & 2-3 times a week & $\begin{array}{c}31 \\
(35 \%)\end{array}$ & $\begin{array}{c}10 \\
(29 \%)\end{array}$ & $\begin{array}{c}0 \\
(0 \%)\end{array}$ & $\begin{array}{c}41 \\
(26 \%)\end{array}$ \\
\hline 3 & Once a week & $\begin{array}{c}12 \\
(14 \%)\end{array}$ & $\begin{array}{c}18 \\
(53 \%)\end{array}$ & $\begin{array}{c}5 \\
(14 \%)\end{array}$ & $\begin{array}{c}35 \\
(22 \%)\end{array}$ \\
\hline 4 & 2-3 times a month & $\begin{array}{c}8 \\
(9 \%)\end{array}$ & $\begin{array}{c}3 \\
(9 \%)\end{array}$ & $\begin{array}{c}3 \\
(8 \%)\end{array}$ & $\begin{array}{c}14 \\
(9 \%)\end{array}$ \\
\hline 5 & Once a month & $\begin{array}{c}17 \\
(19 \%)\end{array}$ & $\begin{array}{c}3 \\
(9 \%)\end{array}$ & $\begin{array}{c}2 \\
(6 \%) \\
\end{array}$ & $\begin{array}{c}22 \\
(14 \%)\end{array}$ \\
\hline 6 & Don't know & $\begin{array}{c}12 \\
(14 \%)\end{array}$ & $\begin{array}{c}0 \\
(0 \%)\end{array}$ & $\begin{array}{c}25 \\
(69 \%)\end{array}$ & $\begin{array}{c}37 \\
(23 \%)\end{array}$ \\
\hline & Total & $\begin{array}{c}88 \\
(100 \%) \\
\end{array}$ & $\begin{array}{c}34 \\
(100 \%)\end{array}$ & $\begin{array}{c}36 \\
(100 \%) \\
\end{array}$ & $\begin{array}{c}158 \\
(100 \%) \\
\end{array}$ \\
\hline
\end{tabular}

Table 4: Frequency of Use of E-resources

The frequency of use of e-Resources indicates its demand between the users. It also justified the huge budget involve in procuring those resources. Table 4 explore the frequency of use of E-resources in the Chandigarh University library. It is nice to identify that $6 \%$ (9) users use the e-Resources daily basis, whereas $26 \%$ (41) users use 2-3 times a week and $22 \%$ (35) users use a minimum once a week. However, when it comes to student usage, unfortunately, 69\% (25) are unaware of their particular frequency. Further investigation reveals that they only use e-Resources when preparing for an assignment or exam and only on rare occasions.

10.6. [SQ6]- Awareness \& Frequency of Use of Different Databases

\begin{tabular}{|l|c|c|c|c|}
\hline Databases & $\begin{array}{c}\text { Use Often } \\
\mathbf{( n \% )}\end{array}$ & $\begin{array}{c}\text { Use } \\
\text { Sometimes } \\
(\mathbf{n} \% \mathbf{)}\end{array}$ & $\begin{array}{c}\text { Never Use } \\
\mathbf{( n \% )}\end{array}$ & $\begin{array}{c}\text { Unfamiliar } \\
\text { with } \\
(\mathbf{n} \% \mathbf{)}\end{array}$ \\
\hline IEEE & 56 & 44 & 25 & 33 \\
$(35.44 \%)$ & $(27.85 \%)$ & $(15.82 \%)$ & $(20.89 \%)$ \\
\hline Manupatra & 46 & 54 & 15 & 43 \\
$(29.11 \%)$ & $(34.18 \%)$ & $(9.49 \%)$ & $(27.22 \%)$ \\
\hline Ebscohost Art \& & 51 & 32 & 32 & 43 \\
Architecture & $(32.28 \%)$ & $(20.25 \%)$ & $(20.25 \%)$ & $(27.22 \%)$ \\
\hline J Gate - JST & 68 & 56 & 22 & 12 \\
& $(43.04 \%)$ & $(35.44 \%)$ & $(13.92 \%)$ & $(7.59 \%)$ \\
\hline J Gate - JSSH & 58 & 66 & 10 & 24 \\
& $(36.71 \%)$ & $(41.77 \%)$ & $(6.33 \%)$ & $(15.19 \%)$ \\
\hline
\end{tabular}




\begin{tabular}{|c|c|c|c|c|}
\hline Web of Science & $\begin{array}{c}58 \\
(36.71 \%) \\
\end{array}$ & $\begin{array}{c}38 \\
(24.05 \%)\end{array}$ & $\begin{array}{c}39 \\
(24.68 \%)\end{array}$ & $\begin{array}{c}23 \\
(14.56 \%)\end{array}$ \\
\hline Pearson (E-Books) & $\begin{array}{c}12 \\
(7.59 \%)\end{array}$ & $\begin{array}{c}13 \\
(8.23 \%)\end{array}$ & $\begin{array}{c}79 \\
(50.00 \%)\end{array}$ & $\begin{array}{c}54 \\
(34.18 \%)\end{array}$ \\
\hline EBSCO (E - Books) & $\begin{array}{c}71 \\
(44.94 \%)\end{array}$ & $\begin{array}{c}52 \\
(32.91 \%)\end{array}$ & $\begin{array}{c}24 \\
(15.19 \%)\end{array}$ & $\begin{array}{c}11 \\
(6.96 \%)\end{array}$ \\
\hline DELNET & $\begin{array}{c}40 \\
(25.32 \%) \\
\end{array}$ & $\begin{array}{c}35 \\
(22.15 \%) \\
\end{array}$ & $\begin{array}{c}53 \\
(33.54 \%) \\
\end{array}$ & $\begin{array}{c}30 \\
(18.99 \%) \\
\end{array}$ \\
\hline $\begin{array}{l}\text { British Council } \\
\text { Library }\end{array}$ & $\begin{array}{c}1 \\
(0.63 \%)\end{array}$ & $\begin{array}{c}2 \\
(1.27 \%)\end{array}$ & $\begin{array}{c}120 \\
(75.95 \%)\end{array}$ & $\begin{array}{c}35 \\
(22.15 \%)\end{array}$ \\
\hline E-Shodh Sindhu & $\begin{array}{c}2 \\
(1.27 \%) \\
\end{array}$ & $\begin{array}{c}6 \\
(3.80 \%) \\
\end{array}$ & $\begin{array}{c}111 \\
(70.25 \%)\end{array}$ & $\begin{array}{c}39 \\
(24.68 \%) \\
\end{array}$ \\
\hline $\begin{array}{l}\text { Shodhganga/Sodh } \\
\text { Gangotri }\end{array}$ & $\begin{array}{c}3 \\
(1.90 \%)\end{array}$ & $\begin{array}{c}4 \\
(2.53 \%)\end{array}$ & $\begin{array}{c}124 \\
(78.48 \%)\end{array}$ & $\begin{array}{c}27 \\
(17.09 \%)\end{array}$ \\
\hline $\begin{array}{l}\text { National Digital } \\
\text { Library of India } \\
\text { (NDL) }\end{array}$ & $\begin{array}{c}5 \\
(3.16 \%)\end{array}$ & $\begin{array}{c}3 \\
(1.90 \%)\end{array}$ & $\begin{array}{c}137 \\
(86.71 \%)\end{array}$ & $\begin{array}{c}13 \\
(8.23 \%)\end{array}$ \\
\hline
\end{tabular}

*Shaded cells indicates the major database of that particular types

Table 5: Awareness \& Frequency of Use of Different Databases

SQ6 tries to evaluate the awareness \& frequency of use of different databases available in the Chandigarh University library. With the recorded responses, from Table 5, it can be easily identified that, among the listed databases, EBSCO (E-books) used most (44.94\% or 71 ) by the users, followed by J Gate - JST (43.04\% or 68), J Gate - JSSH (36.71\% or 58) \& Web of Science (36.71\% or 58). Similarly, the National Digital Library of India (NDL) database is the most unused $(86.71 \%$ or 137$)$ database, and Pearson (E-Books) most unfamiliar $(34.18 \%$ or 54$)$ one.

\section{7. [SQ7]- Formats of E-resources}

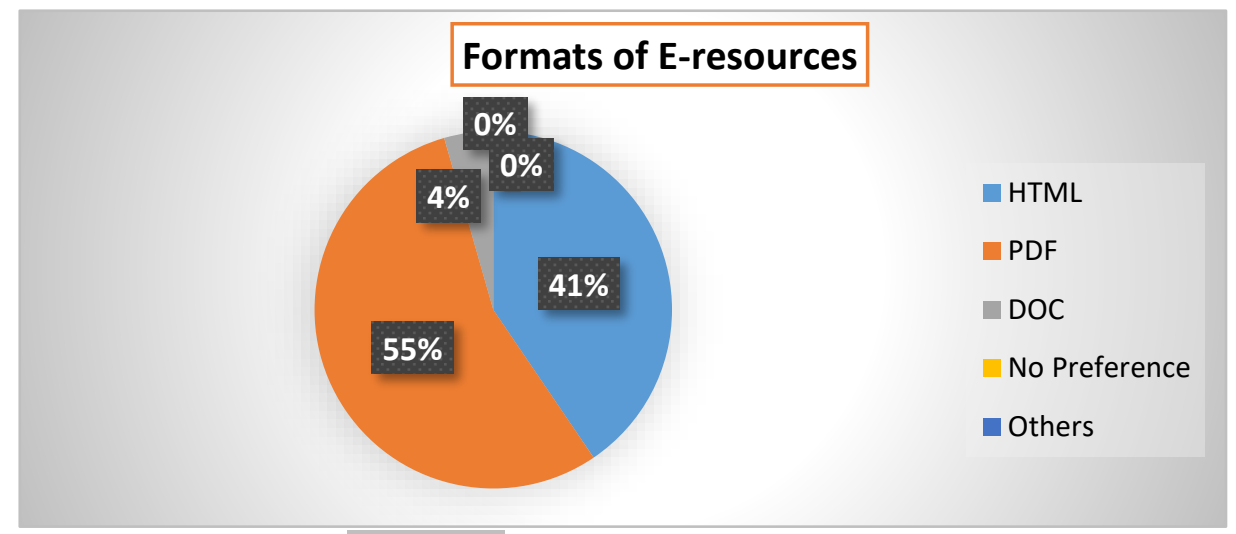

Figure 6: Formats of E-resources

SQ7 identified the most popular file formats for CU E-resources, and Figure $\mathbf{6}$ displays that PDF and HTML are the two most common e-formats used most by the library users in the CU e-repository. According to the findings, 55\% (87) of respondents choose PDF format for using e-resources, 41\% (64) prefer HTML format, and 7 (4\%) others prefer DOC File.

\section{8. [SQ8]- Satisfaction of Accessing E-resources}




\begin{tabular}{|c|c|c|c|c|c|}
\hline \multirow{2}{*}{$\begin{array}{l}\text { Sr. } \\
\text { No. }\end{array}$} & \multirow{2}{*}{ Satisfaction Level } & \multicolumn{4}{|c|}{ No of Respondents } \\
\hline & & Faculty & Staff & Student & Overall \\
\hline 1 & Very Satisfied & $\begin{array}{c}24 \\
(27 \%)\end{array}$ & $\begin{array}{c}11 \\
(32 \%)\end{array}$ & $\begin{array}{c}14 \\
(39 \%)\end{array}$ & $\begin{array}{c}49 \\
(31 \%)\end{array}$ \\
\hline 2 & Satisfied & $\begin{array}{c}30 \\
(34 \%)\end{array}$ & $\begin{array}{c}18 \\
(53 \%)\end{array}$ & $\begin{array}{c}19 \\
(53 \%)\end{array}$ & $\begin{array}{c}67 \\
(42 \%)\end{array}$ \\
\hline 3 & Neutral & $\begin{array}{c}28 \\
(32 \%)\end{array}$ & $\begin{array}{c}5 \\
(15 \%)\end{array}$ & $\begin{array}{c}1 \\
(3 \%)\end{array}$ & $\begin{array}{c}34 \\
(22 \%)\end{array}$ \\
\hline 4 & Dissatisfied & $\begin{array}{c}6 \\
(7 \%) \\
\end{array}$ & $\begin{array}{c}0 \\
(0 \%) \\
\end{array}$ & $\begin{array}{c}2 \\
(6 \%) \\
\end{array}$ & $\begin{array}{c}8 \\
(5 \%) \\
\end{array}$ \\
\hline 5 & $\begin{array}{l}\text { Extremely } \\
\text { Dissatisfied }\end{array}$ & $\begin{array}{c}0 \\
(0 \%)\end{array}$ & $\begin{array}{c}0 \\
(0 \%)\end{array}$ & $\begin{array}{c}0 \\
(0 \%)\end{array}$ & $\begin{array}{c}0 \\
(0 \%)\end{array}$ \\
\hline & Total & $\begin{array}{c}88 \\
(100 \%)\end{array}$ & $\begin{array}{c}34 \\
(100 \%)\end{array}$ & $\begin{array}{c}36 \\
(100 \%) \\
\end{array}$ & $\begin{array}{c}158 \\
(100 \%)\end{array}$ \\
\hline
\end{tabular}

Table 6: Satisfaction Level of Accessing E-resources

With the question SQ8, while ensuring the satisfaction level of accessing E-resources, Table 6 confirmed that the majority (116 or $73 \%$ ) of the respondents are very satisfied or satisfied while accessing E-resources and $34(22 \%)$ others are neutral. Only 5\% (8) users are dissatisfied accessing of e-resources. This result suggests the availability of sufficient \& quality E-resources in the Chandigarh University library.

\section{9. [SQ9]- Difficulties of Accessing E-resources}

\begin{tabular}{|c|l|c|c|}
\hline $\begin{array}{c}\text { Sr. } \\
\text { No. }\end{array}$ & $\begin{array}{l}\text { Problems facing while using the e- } \\
\text { resources }\end{array}$ & $\begin{array}{c}\text { No of } \\
\text { Respondent }\end{array}$ & $\begin{array}{c}\text { \% age of } \\
\text { respondent }\end{array}$ \\
\hline 1 & Computer/network problems & 11 & $\mathbf{7 \%}$ \\
\hline 2 & Lack of searching skills & 8 & $5 \%$ \\
\hline 3 & Lack of up-to-date equipment & 16 & $10 \%$ \\
\hline 4 & Few computers & 13 & $\mathbf{8 \%}$ \\
\hline 5 & Slow internet connectivity & 16 & $1 \%$ \\
\hline 6 & Virus attacks & 39 & $\mathbf{2 5 \%}$ \\
\hline 7 & Overload of information & 37 & $\mathbf{2 3 \%}$ \\
\hline 8 & Difficulty in finding relevant information & 16 & $\mathbf{1 0 \%}$ \\
\hline 9 & Others $\quad$ Total & $\mathbf{1 5 8}$ & $\mathbf{1 0 0} \%$ \\
\hline & $\quad$ Table & 2 & $10 \%$ \\
\hline
\end{tabular}

Table 7: Difficulties of Accessing E-resources

SQ9 shows the problems faced by library users while using the e-resources from the Chandigarh University library website. Though e-resources have become a common source among the academic and research communities, the majority of the users stated that they faced some difficulties while accessing e-resources. Out of the 158 respondents, $25 \%$ (39) are having problems with an overload of information that isn't specified properly, followed by $23 \%$ (37) users with difficulty in finding relevant information. Among the rest, 
$10 \%$ (16) library users are facing the problem due to lack of up-to-date equipment, Slow internet connectivity and others.

\subsection{0. [SQ10]- Satisfaction with the Library Staff}

Chandigarh University library staff check each and every CU subscription twice a day by searching and downloading articles. Once confirmed that each resource is working, library staff prepare a bridge between the library and the library users to update them regularly and assist them if they are facing any difficulty in the use. SQ10 specifically deals at that point by asking the library users whether they are satisfied or not by the service of the library staff in accessing e-Resources.

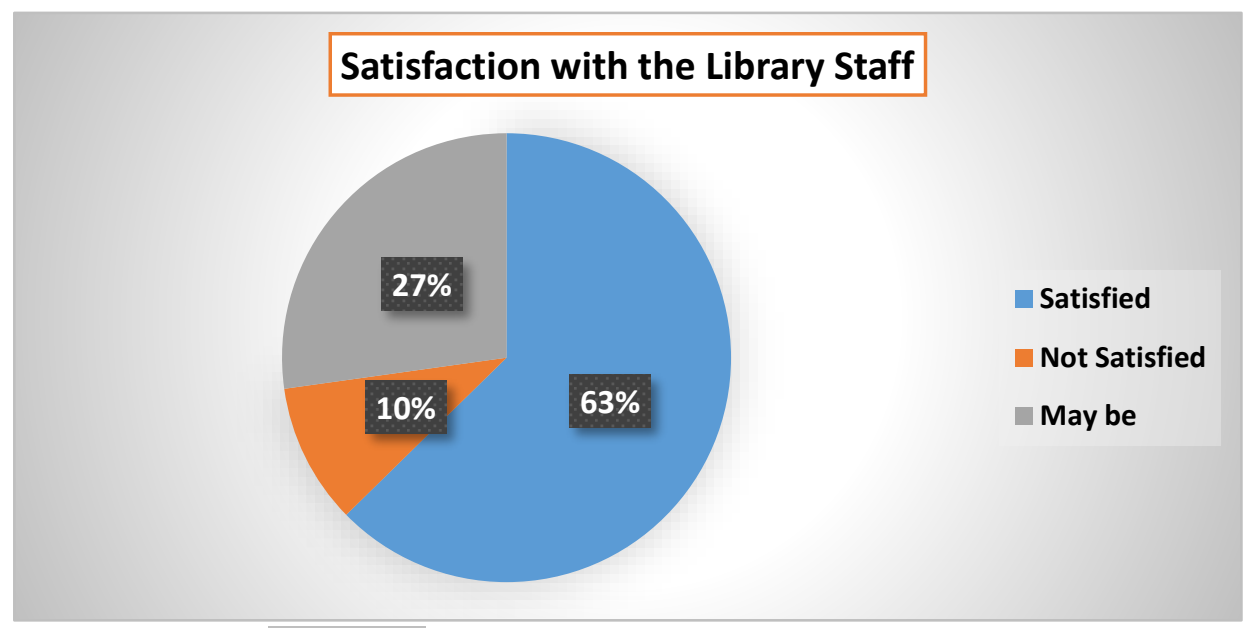

Figure 7: Satisfaction With the Library Staff

Figure 7 shows that the majority ( 99 or $63 \%$ ) of the library users are satisfied with the service of library professionals. Apart from this, 27\% (43) users are not sure about their satisfaction, whereas $10 \%$ (16) are not satisfied with the existing library professionals' assistance while facing problems in accessing e-Resources.h

\subsection{1. [SQ11]- Attending Training/Workshop/Seminar Organized by Library}

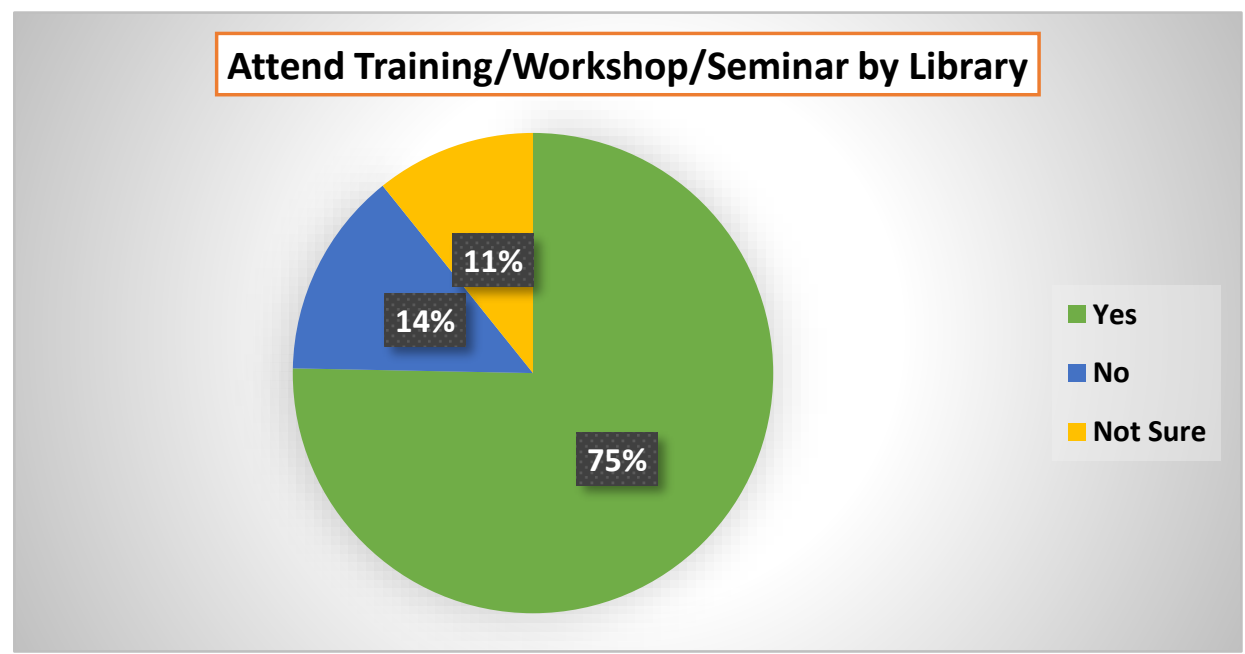

Figure 8: Attend Library Organised Training/Workshop/Seminar for usage of Eresources 
It is the responsibility of the library staff to aware the library users of the availability of eResources in the library, their accessibility criteria and how to use them. Figure $\mathbf{8}$ shows that $75 \%$ (119) library users have attended the training regarding access to electronic resources, while 14\% (22) library users didn't get any training, and the rest $11 \%$ (17) users not sure about this regard. Because the Chandigarh University library organises semesterby-semester training for staff members and an annual orientation programme for students, some of the respondents are probably new to the university campus.

\subsection{2. [SQ12]- Need of any training/workshop/seminar}

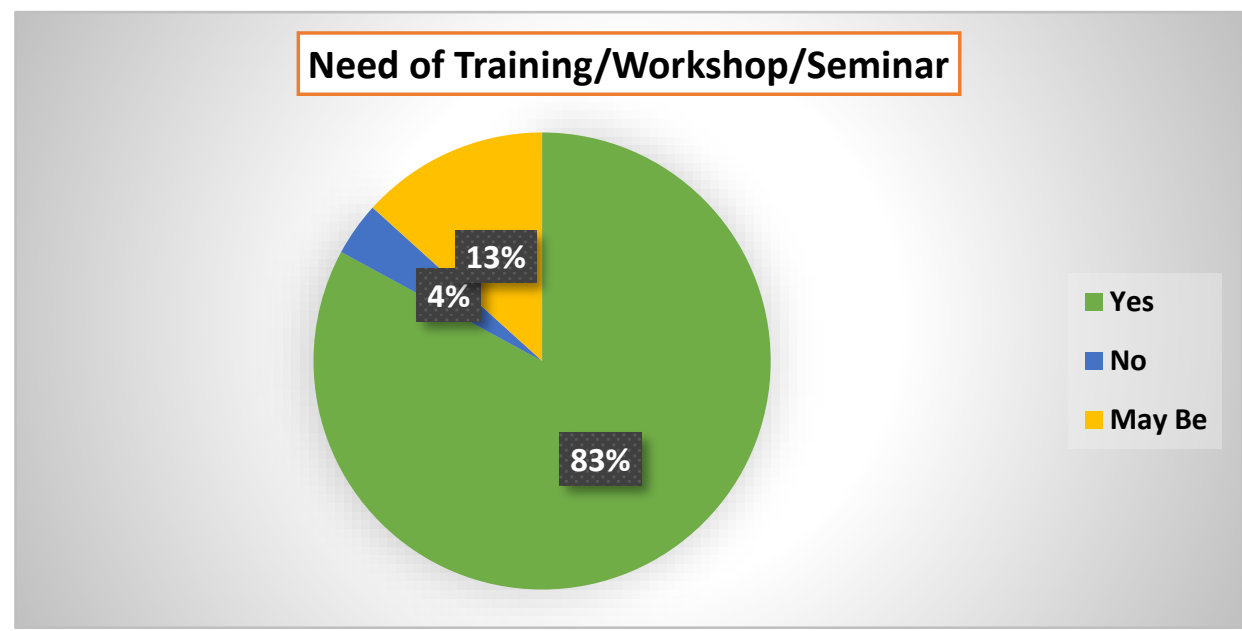

Figure 9: Need of training / workshop / seminar

In Chandigarh University, the library organised training sessions, workshops \& seminars from time to time for the library users \& also for library staff to enhance their skills about how to use different databases \& e-Resources. Figure 9 shows that $83 \%$ (131) library users have a need of training/workshop/seminar, while 4\% (6) users do not want to take any kind of training / workshop/seminar and 21 (13\%) other do not sure about their need.

\section{Recommendations}

This study showed that the uses of e-resources are very common among the students, staff and faculty members. It also showed that the library users are dependent on e-resources to get desired and relevant information. It was however, revealed that practical uses of eresources are not up to the worth in comparison to investments made in acquiring these resources. Moreover, infrastructure and training, programmes are essential for better use of electronic resources campus-wide. It is evident from the analysis that the availability of e-resources on the campus is almost sufficient for all the existing disciplines.

\section{Suggestions}

Form the above findings it is clear that the more and more e-Resources should be provided to the students, staff and faculty members in Knowledge Resource Centre (Central Library) of Chandigarh University.

1) The Knowledge Resource Centre should provide internet accessibility with more number of terminals to the users. 
2) The Knowledge Resource Centre must provide access to online databases access with big number.

3) The knowledge Resource Centre has to conduct formal training/orientation programmes to overcome the obstacles and effective utilization of e-resource.

4) There is a requirement of training and workshop for faculty and Library staff for utilizing e-resources in Chandigarh University, Punjab.

5) Training programme should be organized on time to time for students and faculty regarding how to access the e-resources.

6) Must conduct online sessions about how to explore the digital library in fullfledged manner likewise outcome based education program conducted by UITTR

7) In Web of Science, the access should be for all articles.

8) University need to conduct the workshop that guide the faculty and students to effectively access the information available on e -resources.

9) New bare act should be increased in the Law Department Library

10) Lack of knowledge about e library among students and they ask faculty to explain how to use it.

\section{Conclusion}

The advantages of E-resources have drawn the attention of library users to a great extent. Users are heavily dependent on E-resources for their required information and keep themselves up-to-date in their subject area. Though some expect that the role of libraries as a gateway to the E-resources will have less importance in future as users access more and more E-resources in their respective subjects, it seems to be more hypothetical. Rather, the role of libraries in the age of E-resources will increase tremendously, particularly in providing training and guidance to use authentic and relevant information. The libraries must develop the necessary tools to provide such services to their users satisfactorily. The present survey reveals that all the three categories of the users of Chandigarh University are using the available E-resources convincingly. Simultaneously, the Central Library of Chandigarh University is playing an influential role in promotion, assistance and guidance in accessing the E-resources. Nonetheless, there is enough scope for Central Library to educate its users about the number of E-resources available in the library in each subject area and train them to use the E-resources more effectively.

\section{References}

Haridasan, S., \& Khan, M. (2009). Impact and use of e-resources by social scientists in National Social Science Documentation Centre (NASSDOC), India. The Electronic Library, 27(1), 117-133. https://doi.org/10.1108/02640470910934632

Jogan, S. N. (2015). Access, Awareness And Use Of Electronic Resources By Post Graduate Students In Gulbarga University. International Journal of Informative \& Futuristic Research, 2(6), 1540-1547. https:// files.eric.ed.gov/fulltext/ED597673.pdf

Kurian, B., \& Nagarajan, M. (2018). Awareness and use of Open Access Resources among the Research Scholars of Annamalai University, Tamil Nadu : A Study. Journal of Advances in Library and Information Science, 7(1), 109-114. http://jalis.in/pdf/7-1/Kurian.pdf 
Livina, D. C., \& Mole, A. J. (2021). Academic Staff Use of Electronic Resources (ER) in Nigerian University Libraries During the COVID-19 Lockdown Period. Library Philosophy and Practice (E-Journal), 5341. https://digitalcommons.unl.edu/libphilprac/5341/

Matonkar, P., \& Dhuri, K. (2021). Open Access And Free Resources On The Internet: Awareness And Use During Covid-19 Pandemic. Library Philosophy and Practice (E-Journal), 5153. https://digitalcommons.unl.edu/libphilprac/5153

Mitra, A. (2020). Challenges and Opportunities of E-resources during COVID-19. International Journal of Business and Management Invention (IJBMI), 9(8), 5558. https://doi.org/10.35629/8028-0908015558

N., S., \& N, R. (2019). AWARENESS, ACCESS AND USAGE OF E-RESOURCES AMONG FACULTY MEMBERS IN ARTS AND SCIENCE COLLEGES. Library Philosophy and Practice (E-Journal), 2549. https://digitalcommons.unl.edu/libphilprac/2549/

Nikam, K., \& B, P. (2007). Use of e-journals and databases by the academic community of University of Mysore: A survey. Annals of Library and Information Studies (ALIS), 54(1). http:// nopr.niscair.res.in/handle/123456789/3206

Poornima, N., \& IRN, G. (2005). E-Resources Management through Portal: A Case Study of Technical Information Center. International Conference on Knowledge Management (ICIM2005), 1-19.

Shuling, W. (2007). Investigation and analysis of current use of electronic resources in university libraries. Library Management, 28(1/2), 72-88. https://doi.org/10.1108/01435120710723563

Simmonds, P. L., \& Andaleeb, S. S. (2001). Usage of Academic Libraries: The Role of Service Quality, Resources, and User Characteristics. Library Trends, 49(4), 626634.

https://www.ideals.illinois.edu/bitstream/handle/2142/8368/librarytrendsv49i4 f_opt.pdf?sequence $=1 \&$ isAllowed $=y$

Thanuskodi, S. (2012). Use of E-resources by the Students and Researchers of Faculty of Arts, Annamalai University. International Journal of Library Science, 1(1), 1-7. https://doi.org/10.5923/j.library.20120101.01 